ZOOLOGIA 29 (1): 39-53, February, 2012

doi: $10.1590 /$ S1984-46702012000100005

\title{
Introduced and native Phlebobranch and Stolidobranch solitary ascidians (Tunicata: Ascidiacea) around Salvador, Bahia, Brazil
}

\author{
Rosana M. Rocha ${ }^{1,2}$, Nadia Y.K. Bonnet ${ }^{1}$, Mariah S. Baptista ${ }^{1} \&$ Fabiele S. Beltramin ${ }^{1}$ \\ 1 Laboratório de Ecologia e Sistemática de Ascídias, Departamento de Zoologia, Universidade Federal do Paraná. \\ Caixa Postal 19020, 81531-980 Curitiba, PR, Brazil. \\ 2 Corresponding author. E-mail: rmrocha@ufpr.br
}

\begin{abstract}
The Port of Salvador $\left(12^{\circ} 58^{\prime} \mathrm{S}, 38^{\circ} 30^{\prime} \mathrm{W}\right)$ receives cargo ships from different regions such as southeast Asia, North Atlantic, Mediterranean, Africa, North and South America. Thus, the presence of this port enhances the probability of new species arriving and establishing in Todos os Santos Bay (TSB), in which the port is located. Ascidians are sessile filter-feeding invertebrates with short lived larvae and thus are good indicators of bioinvasion. We surveyed the ascidian fauna on three different occasions: August 1999, June 2004 and December 2007. Nineteen species were identified belonging to the following families: Ascidiidae (Phallusia nigra, Ascidia cf. multitentaculata, A. nordestina, A. papillata, A. scalariforme, A. cf. tapuni, A. tenue), Corellidae (Rhodosoma turcicum), Pyuridae (Microcosmus anchylodeirus, M. exasperatus, M. helleri, Pyura vittata, Herdmania pallida), and Styelidae (Polycarpa cf. reviviscens, P. spongiabilis, P. tumida, Polycarpa sp., Styela canopus, Cnemidocarpa irene). Only A. nordestina, A. papillata, A. scalariforme and P. spongiabilis are possibly native to this region, while $P$. tumida and $C$. irene were classified as introduced. Microcosmus anchylodeirus, H. pallida, P. vittata, M. exasperatus, M. helleri, S. canopus, A. cf. multitentaculata, A. tenue and $P$. nigra were classified as cryptogenic. Most are widely distributed in all oceans and their native geographic distribution is unknown, while $A$. cf. multitentaculata and $A$. tenue occur only in the Atlantic, with disjunct distributions. Polycarpa cf. reviviscens, P. tumida and $M$. anchylodeirus are registered for the first time on the coast of Brazil. Colonial ascidians from this collection are still being studied. The large number of cryptogenic and introduced species indicates the necessity of monitoring TSB for expansion of these populations and the need for the establishment of control programs.
\end{abstract}

KEY WORDS. Baía de Todos os Santos; biodiversity survey; exotic species; sea squirt.

The first reports of ascidians on the coast of Brazil date back to the great oceanographic expeditions at the end of the nineteenth century, published by TRAUSTEDT $(1882,1883)$, HERDMAN $(1882,1886)$, Michaelsen $(1907,1923)$ and HARTMEyer $(1912)$. Since then, the southeastern region has been the most intensively studied, but a survey of the literature shows that the number of ascidian records is positively correlated with collecting effort, suggesting that this fauna is still far from being well known.

The tropical northeastern Brazilian state of Bahia has a long coast that is still poorly studied. Only ten species have been reported prior to this study: Aplidium crassum Herdman, 1886 (possibly Clavelina picta according to VAN NAME (1945) but only Clavelina oblonga has been reported since then), Diazona gigantea (Sluiter, 1919) (accepted as Stomozoa gigantea (Van Name, 1921)), Rhopalaea abdominalis (Sluiter, 1898), Ascidia interrupta Heller, 1978, Polycarpa foresti Monniot, 1970, Polycarpa pilella (Herdman, 1881) (Polyandrocarpa pilella according to VAN NAME (1945)), Polyandrocarpa (Monandrocarpa) stolonifera Monniot, 1970 (accepted as Monandrocarpa stolonifera), Microcosmus goanus Michaelsen, 1918 (accepted as M. helleri Herdman, 1881), Molgula salvadori Monniot, 1970, and Molgula eugyroides Traustedt, 1883. Lotufo \& SILVA (2006) mention several colonial ascidians as often found in northeastern Brazil, but no specific localities in Bahia have been reported.

Greater ascidian diversity is expected in Bahia, given that the waters are tropical and that more than 60 species, many tropical, have been reported from southern Brazil (RocHA et al. 2011). This expectation was supported by three studies (August 1999, June 2004 and December 2007) in several locations within and near the mouth of the Todos os Santos Bay (TSB). Greater concern for introductions is also due to the fact that Salvador was the first capital of Brazil (1534 to 1763) at which time the Port of Salvador was the most important international and regional Brazilian port. It is still important regionally and internationally with intense ship traffic due to which non-native species are expected to be found.

With these considerations, we examined the solitary ascidian community of Todos os Santos Bay. We place this community in a historical context to better determine whether these species are natives, introduced or cryptogenic. With this infor- 
mation, we begin to better understand the dynamics of introductions in this bay and to suggest possible methods for monitoring and control when necessary.

\section{MATERIAL AND METHODS}

Specimens were collected while scuba diving during one week in August 1999, June 2004 and December 2007 (Tab. I, Fig. 1). Searches for species at each site lasted for approximately two hours. Sites were not always visited in all years. All species seen were collected, but no effort was made to quantify their abundance. Animals were photographed prior to collecting to aid in their identification.

Specimens were collected, anesthetized and fixed following standard procedures (MonNIOT \& MonNioT 1972). The classification of the species as native, cryptogenic or introduced followed Chapman \& Carlton $(1991,1994)$, that is, using wide and/or disjunctive geographic distribution, presence in port regions and artificial substrates, association with other introduced species, recent expansion of geographical distribution, and absence in earlier surveys of the region, as criteria to indicate introductions. We also used literature reports of introduction in other localities as an indicative of human transport ability. The absence of knowledge of original geographical distribution was used as criteria to classify the species as cryptogenic.

Specimens were deposited in the Ascidiacea collection of the Departamento de Zoologia, Universidade Federal do Paraná (DZUP) and in the Museu de Zoologia, Universidade de São Paulo (MZUSP). Keys for the identification of the specimens are included.

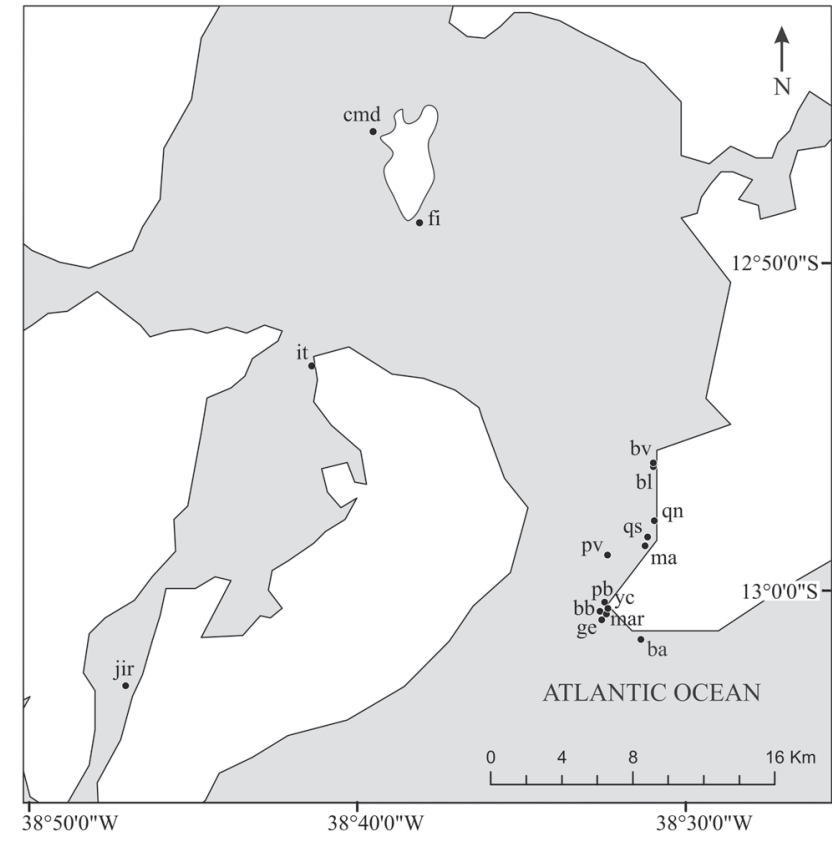

Figure 1. Collecting sites in Todos os Santos Bay, Bahia, Brazil. (cmd) Canal Madre Deus, (fi) Frades Island, (it) Itaparica pier, (bv) Boa Viagem beach, (bl) shipwreck Blackadder, (qn) Quebramar Norte, (qs) Quebramar Sul, (ma) Bahia Marina, (yc) Yacht club, (pv) Pedra Verde, (mar) shipwreck Maraldi, (bb) Barra bouy, (ge) shipwreck Germania, (pb) Porto da Barra, (ba) Barra, (jir) Jiribatuba.

Table I. Sites visited during rapid assessments for ascidians in Todos os Santos Bay regions, state of Bahia, Brazil.

\begin{tabular}{|c|c|c|c|c|c|c|c|}
\hline Site name & \multicolumn{2}{|c|}{ Coordinates } & Depth (m) & 1999 & 2004 & 2007 & Description \\
\hline Canal Madre Deus (cmd) & $12^{\circ} 45^{\prime} 41^{\prime \prime} \mathrm{S}$ & $38^{\circ} 39^{\prime} 13^{\prime \prime} \mathrm{W}$ & & & $x$ & & Granite boulders \\
\hline Frades island (fi) & $12^{\circ} 48^{\prime} 51^{\prime \prime} \mathrm{S}$ & $38^{\circ} 38^{\prime} 08^{\prime \prime} \mathrm{W}$ & $0-5$ & $x$ & & $x$ & Coral reef \\
\hline Itaparica pier (it) & $12^{\circ} 53^{\prime} 30^{\prime \prime} \mathrm{S}$ & $38^{\circ} 41^{\prime} 02^{\prime \prime} \mathrm{W}$ & $0-2$ & $x$ & & & Pier \\
\hline Boa Viagem beach (bv) & $12^{\circ} 55^{\prime} 56^{\prime \prime} \mathrm{S}$ & $38^{\circ} 30^{\prime} 50^{\prime \prime} \mathrm{W}$ & $0-5$ & $x$ & & & Shipwreck on sand \\
\hline shipwreck Blackadder (bl) & $12^{\circ} 56^{\prime} 06^{\prime \prime} S$ & $38^{\circ} 30^{\prime} 42^{\prime \prime} \mathrm{W}$ & $0-7$ & & & $x$ & Shipwreck on sand \\
\hline Quebramar Norte (qn) & $12^{\circ} 57^{\prime} 52^{\prime \prime} S$ & $38^{\circ} 30^{\prime} 57^{\prime \prime} \mathrm{W}$ & $3-12$ & $x$ & $x$ & $x$ & Riprap made of granite boulders \\
\hline Quebramar Sul (qs) & $12^{\circ} 58^{\prime} 22^{\prime \prime} \mathrm{S}$ & $38^{\circ} 31^{\prime} 09^{\prime \prime} \mathrm{W}$ & $3-12$ & $x$ & $x$ & $x$ & Riprap made of granite boulders \\
\hline Bahia Marina (ma) & $12^{\circ} 58^{\prime} 38^{\prime \prime} \mathrm{S}$ & $38^{\circ} 31^{\prime} 14^{\prime \prime} \mathrm{W}$ & $3-12$ & $x$ & & $x$ & Riprap made of granite boulders \\
\hline Yacht Club (yc) & $12^{\circ} 59^{\prime} 57^{\prime \prime} \mathrm{S}$ & $38^{\circ} 31^{\prime} 52^{\prime \prime} \mathrm{W}$ & $3-5$ & & & $x$ & Granitic boulders on sand \\
\hline Pedra Verde (pv) & $12^{\circ} 57^{\prime} 27^{\prime \prime} \mathrm{S}$ & $38^{\circ} 32^{\prime} 29^{\prime \prime} \mathrm{W}$ & 23 & $x$ & & & Granitic boulders on sand \\
\hline shipwreck Maraldi (mar) & $13^{\circ} 00^{\prime} 31^{\prime \prime} \mathrm{S}$ & $38^{\circ} 32^{\prime} 02^{\prime \prime} \mathrm{W}$ & $0-6$ & & & $x$ & Shipwreck on sand \\
\hline Barra bouy (bb) & $13^{\circ} 00^{\prime} 32^{\prime \prime} \mathrm{S}$ & $38^{\circ} 32^{\prime} 19^{\prime \prime} \mathrm{W}$ & $10-15$ & & & $x$ & Coral reef \\
\hline shipwreck Germania (ge) & $13^{\circ} 00^{\prime} 34^{\prime \prime} \mathrm{S}$ & $38^{\circ} 31^{\prime} 59^{\prime \prime} \mathrm{W}$ & $0-7$ & & & $x$ & Shipwreck on sand \\
\hline Porto da Barra (pb) & $13^{\circ} 00^{\prime} 14^{\prime \prime} S$ & $38^{\circ} 32^{\prime} 01^{\prime \prime} \mathrm{W}$ & $0-5$ & $x$ & $x$ & $x$ & Granitic boulders on sand \\
\hline Barra (ba) & $13^{\circ} 00^{\prime} 37^{\prime \prime} \mathrm{S}$ & $38^{\circ} 31^{\prime} 41^{\prime \prime} \mathrm{W}$ & $0-10$ & $x$ & $x$ & & Granitic boulders on sand and coral \\
\hline Jiribatuba (jir) & $13^{\circ} 03^{\prime} 29^{\prime \prime} \mathrm{S}$ & $38^{\circ} 47^{\prime} 51^{\prime \prime} \mathrm{W}$ & $0-5$ & & $x$ & & Granitic boulders on sand \\
\hline
\end{tabular}




\section{TAXONOMY}

Nineteen species of solitary ascidians were found, 18 of which were identified to species, and in the following families (Tab. II): Ascidiidae (Phallusia nigra, Ascidia cf. multitentaculata, A. nordestina, A. papillata, A. scalariforme, A. cf. tapuni, A. tenue), Corellidae (Rhodosoma turcicum), Pyuridae (Microcosmus anchylodeirus, M. exasperatus, M. helleri, Pyura vittata, Herdmania pallida), and Styelidae (Polycarpa cf. reviviscens, P. spongiabilis, P. tumida, Polycarpa sp., Styela canopus, Cnemidocarpa irene).

Shallower sites $(<10 \mathrm{~m})$ with a granite substrate had a greater number of species (Quebramar norte, Quebramar sul, Bahia marina and Porto da Barra), while places with fewer species had variable salinity (Canal Madre de Deus, Frade island, Jiribatuba), were deep (Pedra Verde and Barra Bouy, > $15 \mathrm{~m}$ ) or were shipwrecks (Blackadder, Maraldi, Germania) (Tab. II).

\section{Key for the identification of the families}

1 Body musculature: B - well developed on both sides; R - only developed on the right side

2 Oral tentacles: $\mathrm{R}$ - Ramified; S - Simple

3 Dorsal lamina: C - Continuous; L - Divided in languets

4 Number of folds on pharynx wall (one side)

5 Pharyngeal papillae: 0 - Absent; $\mathrm{C}$ - Papillae project into the lumen from complete longitudinal vessels; $\mathrm{S}$ - Papillae support longitudinal vessels without projecting into the lumen

6 Pharyngeal stigmata: S - Straight; C - Curved

7 Position of the alimentary canal in relation to the pharynx: L - Left side; $\mathrm{R}$ - Right side

8 Number of gonads or gonad lobes on the right side 9 Number of gonads or gonad lobes on the left side

10 Peculiar characteristics: G - Stomach with digestive gland; $\mathrm{V}$ - small renal vesicles on the wall of the alimentary canal

\begin{tabular}{ccccccccccc}
\hline $\mathbf{1}$ & $\mathbf{2}$ & $\mathbf{3}$ & $\mathbf{4}$ & $\mathbf{5}$ & $\mathbf{6}$ & $\mathbf{7}$ & $\mathbf{8}$ & $\mathbf{9}$ & $\mathbf{1 0}$ & Family \\
\hline R & S & C & 0 & C & S & L & 0 & 1 & V & Ascidiidae \\
B & S & L & 0 & S & S & R & 1 & 0 & - Corellidae \\
B & S & C & 4 & 0 & S & L & $2-100$ & $2-50$ & - Styelidae \\
B & R & C, L & $6-10$ & 0 & S, C & L & $1-50$ & $1-50$ & G & Pyuridae \\
\hline
\end{tabular}

\section{Order Phlebobranchia Lahille, 1886}

\section{Ascidiidae Herdman, 1882}

1 Coloration in life: G - Gray; Bl - Black; O - Orange; S - Covered by sand; U - Uncolored

2 Projections in the siphon margin lobes: 0 - Absent; $\mathrm{P}$ - Present

3 Musculature on the right side: $\mathrm{B}$ - Parallel short fibers forming a band around the margin; D - Parallel short fibers forming a band only on the dorsal margin; $\mathrm{V}$ - In various directions 4 Number of oral tentacles
5 Accessory openings along the neural gland duct: 0 - Absent; P - Present

6 Papillae on the right side of the dorsal lamina, near the esophageal aperture: 0 - Absent; P - Present

7 Number of plications on the stomach wall

8 Dilation on the posterior intestine: 0 - Absent; P - Present

9 Form of the ovary: C - Cauli-flower; $\mathrm{R}$ - Ramified

\begin{tabular}{cccccccccl}
\hline $\mathbf{1}$ & $\mathbf{2}$ & $\mathbf{3}$ & $\mathbf{4}$ & $\mathbf{5}$ & $\mathbf{6}$ & $\mathbf{7}$ & $\mathbf{8}$ & $\mathbf{9}$ & \multicolumn{1}{c}{ Species } \\
\hline $\mathrm{S}$ & $\mathrm{P}$ & $\mathrm{B}$ & $100-250$ & 0 & 0 & $3-4$ & 0 & $\mathrm{R}$ & Ascidia cf. multitentaculata \\
$?$ & $\mathrm{P}$ & $\mathrm{V}$ & $78-99$ & 0 & $\mathrm{P}$ & $5-7$ & 0 & $\mathrm{R}$ & A. nordestina \\
? & $\mathrm{P}$ & $\mathrm{D}$ & 259 & 0 & $\mathrm{P}$ & $4-5$ & 0 & $\mathrm{R}$ & A. papillata \\
$\mathrm{U}$ & 0 & $\mathrm{~B}$ & $63-147$ & 0 & $\mathrm{P}$ & $7-10$ & $\mathrm{P}$ & $\mathrm{R}$ & A. scalariforme \\
$\mathrm{U}$ & 0 & $\mathrm{~V}$ & $71-165$ & 0 & $\mathrm{P}$ & $6-8$ & 0 & $\mathrm{C}$ & A. tenue \\
$\mathrm{O}$ & 0 & $\mathrm{~V}$ & $84-102$ & 0 & 0 & $0-2$ & $\mathrm{P}$ & $\mathrm{R}$ & A. cf. tapuni \\
$\mathrm{G}, \mathrm{BI}$ & 0 & $\mathrm{~V}$ & $27-71$ & $\mathrm{P}$ & 0 & $6-7$ & $\mathrm{P}$ & $\mathrm{C}$ & Phallusia nigra \\
\hline
\end{tabular}

\section{Ascidia cf. multitentaculata Hartmeyer, 1912}

This species was recently reported in BONNET \& ROCHA (2011) with the following diagnosis: siphon lobe border with projections; body musculature on the right side comprising short fibers perpendicular to the body margin, leaving a central region without musculature; 100-250 oral tentacles; dorsal tubercle Ushaped, with convoluted ends; prepharyngeal area usually with papillae, but are absent in some individuals; isodiametric intestine; anus bilobed; ovary ramified on the intestine wall.

Examined material. Shipwreck Blackadder (4-5 m depth) 14/XII/2007 (1 ind., DZUP ASC89). Boa Viagem beach (5 m depth, under rock), 03/VIII/1999 (1 ind., DZUP ASC88). Salvador (intertidal), 12/VIII/1999 (2 ind., PALB BA SA31). Porto da Barra (4 m depth), 06/VI/2004 (1 ind., DZUP ASC42).

Distribution along the coast of Brazil: Ceará (Lotufo \& Silva 2006); Bahia (Millar 1977); Espírito Santo, São Paulo (BonNET \& Rocha 2011). World Distribution: Brazil, South Africa.

\section{Ascidia nordestina Bonnet \& Rocha, 2011}

The species was recently described (BONNET \& Rocha 2011) with the following diagnosis: siphon border with projections; body musculature as a net on the right side of the body; prepharyngeal groove with long projections on the anterior margin; papillae in the prepharyngeal area; papillae on the right face of the dorsal lamina near to the esophageal aperture; 3-5 stigmata per mesh; 5-7 longitudinal folds in the stomach; isodiametric intestine; ovary ramified.

Examined material. Porto da Barra (3-5 m depth), 16/ XII/2007 (1 ind., MZUSP 00024). Porto da Barra (3-5 m depth), 16/XII/2007 (2 ind., DZUP ASC176).

Distribution along the coast of Brazil: Pernambuco and Bahia (BonNet \& Rocha 2011). World Distribution: Brazil. 
Table II. Spatial distribution of solitary ascidians in Todos os Santos Bay, Bahia and their classification $(\mathrm{N}=$ native, $\mathrm{C}=\mathrm{cryptogenic}, \mathrm{I}=$ introduced).

\begin{tabular}{|c|c|c|c|c|c|c|c|c|c|c|c|c|c|c|c|c|}
\hline & & $\mathrm{cmd}^{1}$ & fi & it & bv & bl & qn & qs & ma & pv & mar & $\mathrm{bb}$ & ge & $\mathrm{pb}$ & ba & jir \\
\hline \multicolumn{17}{|l|}{ Ascidiidae } \\
\hline Ascidia cf. multitentaculata & $\mathrm{C}$ & & & & $x$ & $x$ & & & & & & & & $x$ & & \\
\hline A. nordestina & $\mathrm{N}$ & & & & & & & & & & & & & $x$ & & \\
\hline A. papillata & $\mathrm{N}$ & & $x$ & & & & & & & & & & & & & \\
\hline A. scalariforme & $\mathrm{N}$ & & $x$ & & & $x$ & & & $x$ & & & & & $x$ & & \\
\hline A. cf. tapuni & I & & & & & & & $x$ & & & & & & & & \\
\hline A. tenue & $\mathrm{C}$ & & & & & & & & & & & & & $x$ & & \\
\hline Phallusia nigra & C & $x^{2}$ & & & & & $x^{2}$ & $x$ & & & & & & & & $x$ \\
\hline \multicolumn{17}{|l|}{ Corellidae } \\
\hline Rhodosoma turcicum & $\mathrm{C}$ & & & & & & $x$ & & & & & & & $x^{2}$ & & \\
\hline \multicolumn{17}{|l|}{ Pyuridae } \\
\hline Herdmania pallida & $\mathrm{C}$ & $x$ & $x$ & $x$ & & & $x$ & $x$ & $x$ & & & & & $x$ & & $x$ \\
\hline Microcosmus anchylodeirus & $\mathrm{C}$ & & & & & $x$ & $x$ & $x$ & $x$ & & $x$ & $x$ & $x$ & $x$ & $x$ & \\
\hline Microcosmus exasperatus & C & & $x$ & $x$ & $x$ & & $x$ & $x$ & $x$ & & & & & $x$ & & \\
\hline Microcosmus helleri & $\mathrm{C}$ & & & & & & $x$ & & $x$ & & & & & $x$ & & \\
\hline Pyura vittata & C & & & $\mathrm{X}$ & $x$ & $x$ & $x$ & $x$ & & & $x$ & & $x$ & $x$ & $\mathrm{X}$ & \\
\hline \multicolumn{17}{|l|}{ Styelidae } \\
\hline Polycarpa arnoldi & $\mathrm{C}$ & & & & & & & & $x$ & & & & & & & \\
\hline P. cf. reviviscens & - & & & & & & $x$ & & & $x$ & & & & & & \\
\hline P. spongiabilis & $\mathrm{N}$ & & $x$ & & & & $x$ & & & & & & & & & \\
\hline P. tumida & 1 & & & $x$ & & & & & & & & & & & & \\
\hline Polycarpa sp. & - & & & & & & & & & & & & & & $x$ & \\
\hline Styela canopus & C & & & & & & $x$ & & $x$ & & & & & & & \\
\hline Cnemidocarpa irene & 1 & & & & & & $x$ & & & & & & & & & \\
\hline Total & & 1 & 5 & 4 & 3 & 4 & 10 & 6 & 6 & 1 & 2 & 1 & 2 & 10 & 3 & 2 \\
\hline
\end{tabular}

${ }^{1} \mathrm{cmd}=$ Canal Madre Deus, fi = Frades Island, it = Itaparica pier, bv = Boa Viagem beach - shipwreck, bl = shipwreck Blackadder, qn = Quebramar Norte, qs = Quebramar Sul, ma = Bahia Marina, pv = Pedra Verde, mar = shipwreck Maraldi, $b b=$ Barra bouy, ge = shipwreck Germania, $\mathrm{pb}=$ Porto da Barra, ba = Barra, jir = Jiribatuba

${ }^{2}$ Only observed but not collected.

\section{Ascidia papillata Bonnet \& Rocha, 2011}

The species was recently described (Bonnet \& Rocha 2011) with the following diagnosis: body musculature on the right side formed only by short perpendicular fibers along the dorsal margin of the body, leaving the central and ventral areas without musculature; approximately 200 oral tentacles; dorsal tubercle U-shaped, without enrolled ends; papillae in the prepharyngeal area and on the right side of the dorsal lamina close to the esophageal aperture; stomach with 4-5 longitudinal folds; isodiametric intestine; ovary ramified.

Examined material. Frades island (3-4 m depth), 15/XII/ 2007 (1 ind., MZUSP 00025).

Distribution along the coast of Brazil: Bahia (BONNET \& RосHA 2011). World Distribution: Brazil.

\section{Ascidia scalariforme Bonnet \& Rocha, 2011}

The species was recently described (BONNET \& ROCHA 2011) with the following diagnosis: tunic with small conical papillae; short muscular fibers, perpendicular to the ventral, dorsal and posterior margins on the right side, leaving a central region without musculature; sparse musculature on the siphons; papillae present in the prepharyngeal area and on the dorsal lamina close to the esophageal aperture; dilated posterior intestine; smooth anus; ovary ramified on the primary and secondary intestinal loop.

Examined material. Porto da Barra (3-5 m depth), 16/ XII/2007 (1 ind., MZUSP 00026). Frades island (10 m depth), 07/VI/2004 (1 ind., DZUP ASC102). Frades island (4 m depth), 15/XII/2007 (1 ind., DZUP ASC105). Porto da Barra (3-5 m depth), 16/XII/2007 (2 ind., DZUP ASC106). Porto da Barra (3- 
$5 \mathrm{~m}$ depth), 16/XII/2007 (2 ind., MZUSP 00027). Blackadder shipwreck (6-7 m depth, under rock), 14/XII/2007 (1 ind., DZUP ASC104). Bahia Marina (5 m depth, under rock), 03/VIII/1999 (2 ind., DZUP ASC174). Yacht Club (3-4 m depth), 13/XII/2007 (1 ind., DZUP ASC103).

Distribution along the coast of Brazil: Bahia and São Paulo (BonNet \& Rocha 2011). World Distribution: Brazil.

\section{Ascidia cf. tapuni Monniot and Monniot, 1987}

The species was recently reported (BONNET \& Rocha 2011) with the following diagnosis: animals have orange siphons when alive; musculature on the right side of the body is formed by a net of fibers; prepharyngeal groove with projections in the anterior lamina; dorsal tubercle U-shaped, with convoluted ends; few longitudinal vessels in the pharynx (33-34 in each side); 3-4 stigmata per mesh; posterior intestine with dilation but not a sac-like pouch; ovary ramified.

Examined material. Quebramar Sul, 14/XII/2007 (1 ind., DZUP ASC182).

Distribution along the coast of Brazil: Bahia and Rio de Janeiro (Bonnet \& Rocha 2011). World Distribution: Brazil, Tahiti, New Caledonia, Fiji Is., Indonesia.

\section{Ascidia tenue Monniot, 1983}

The species was recently reported (BONNET \& ROCHA 2011) with the following diagnosis: musculature on right side of body forming net of thin fibers; dorsal tubercle U-shaped, with or without inrolled ends; presence of papillae in prepharyngeal area and on right face of dorsal lamina, close to esophageal aperture; 3-5 stigmata per mesh; 6-8 longitudinal folds in stomach; isodiametric intestine; ovary lobed inside both intestinal loops. Other descriptions can be found in VAN NAME (1945) and Monniot (1972b, 1983a).

Examined material. Porto da Barra (3-5 m depth), 16/ XII/2007 (1 ind., DZUP ASC64).

Distribution along the coast of Brazil: Bahia, São Paulo, Paraná, Santa Catarina (BonNet \& Rocha 2011). World Distribution: Brazil, Caribbean Sea.

\section{Phallusia nigra Savigny, 1816}

This is a well known species of tropical waters and a detailed description can be found in VAN NAME (1945). Only the diagnosis will be given here: tunic smooth and black (but young individuals might present a grayish color); peripharyngeal area with many papillae; 16-36 accessory openings along the neural gland duct; longitudinal vessels in pharynx converging to the dorsal lamina in the anterior region; anus multilobed.

Examined material. Quebramar Sul, 07.VIII.1999 (1 ind., DZUP PHA25). Quebramar Sul (2-3 m depth), 10.VI.2004 (4 ind., DZUP PHA10). Quebramar Sul (4-6 m depth), 14.XII.2007 (3 ind., DZUP PHA28). Jiribatuba (1 m depth), 09.VI.2004 (1 ind., DZUP PHA05).
Distribution along the coast of Brazil: Ceará (Lotufo \& SiLva 2006), Alagoas and Espírito Santo (T.M.C. Lotufo, pers. comm. 2002), Bahia (this study), Rio de Janeiro (Monniot 196970, Rocha \& Costa 2005, Marins et al. 2010), São Paulo (VAN Name 1945, Millar 1958, Rodrigues et al. 1998, Rocha et al. 2011). World Distribution: Brazil, Caribbean Sea, Mediterranean Sea, Red Sea, Indopacific.

Remarks. Although not collected, the species is also common elsewhere in the region (Tab. II).

\section{Corellidae}

\section{Rhodosoma turcicum (Savigny, 1816)}

The specimen observed agrees with the descriptions available (VAN NAME 1945, KотT 1985), but being the first record for the species in Brazil, we will describe it here.

Animals can reach up $5.3 \mathrm{~cm}$ of total length. When alive, the tunic is yellowish or greenish with siphons red, but the color disappeared after fixation. The individual was attached to the substrate by the right side of the body and had epibionts (algae, hydrozoans) on the free surface. The siphons are protected by a lip of the tunic, which has numerous conical papillae. The oral and atrial siphons have eight and six smooth lobes, respectively.

The elongated body is completely transparent. The corporal musculature is restricted to few (4-8 in each side of the body), short and thick longitudinal bands, which extend from the siphons until the region of the first intestinal loop. Also there are thin circular and longitudinal fibers in the siphons.

There are 20-28 simple oral tentacles of two or three sizes. Neither the peripharyngeal groove nor the pre-pharyngeal space have papillae. The dorsal tubercle is horseshoe shaped; the ends of the dorsal tubercle are slightly enrolled. The dorsal lamina is divided in long languets; on the right side of the esophageal aperture there is another row of languets. The pharynx have 72-81 longitudinal vessels in each side, 4-5 stigmata per mesh, and primary papillae under the vessels, not extended to the lumen of the pharynx. The longitudinal vessels may be interrupted in some parts of the pharynx. Parastigmatic vessels and secondary papillae absent.

The rounded stomach is small, with 16-20 longitudinal folds; it is in vertical position. The intestine is isodiametric; the rectum is long, reaching up close to the atrial aperture; anus multilobed.

The ovary is ramified, covering almost all of the primary intestinal loop. The testis is formed by elongated follicles. The gonoducts open anterior to the anus.

Examined material. Quebramar Norte (6-10 m depth), 11.XII.2007 (1 ind., DZUP RHO01).

World distribution. Brazil, Caribbean Sea, Red Sea, Indopacific.

Remarks. There are only two species known in the genus Rhodosoma, and R. turcicum is the most common, widely dis- 
tributed in warm waters. The present material agrees with previous descriptions from elsewhere in the Atlantic and Pacific Oceans (Van Name 1945, KotT 1985).

\section{Order Stolidobranchia Lahille, 1887 Pyuridae Hartmeyer, 1908}

1 Coloration in life: P - Purple; B - Brown; O - Orange; S Covered by sand; R - Red; W - Whitish

2 Number of oral tentacles

3 Number of pharyngeal folds (each side)

4 Shape of the lobes of the digestive gland: $\mathrm{L}$ - Lamelar; $\mathrm{T}$ Tubular

5 Form of the ovary: L - Lobed; S - Saculiform; E - Elongated 6 Number of gonads or gonad lobes on the right side 7 Number of gonads or gonad lobes on the left side

8 Endocarps: A - Absent; B - On the body wall; I - On the intestine wall; $\mathrm{G}$ - On the gonads

9 Peculiar characters: D - Intestinal dilation; S - Spines on the oral siphon; C - Calcareous spicules on the body wall

\begin{tabular}{cccccccccl}
\hline $\mathbf{1}$ & $\mathbf{2}$ & $\mathbf{3}$ & $\mathbf{4}$ & $\mathbf{5}$ & $\mathbf{6}$ & $\mathbf{7}$ & $\mathbf{8}$ & $\mathbf{9}$ & \multicolumn{1}{c}{ Species } \\
\hline B, P & $12-40$ & 7 & L & S & 1 & 1 & B, G & S & $\begin{array}{l}\text { Microcosmus } \\
\text { anchylodeirus }\end{array}$ \\
B, O & $12-25$ & $7-10$ & L & L & $3-5$ & $2-3$ & A, I & S & M. exasperatus \\
P, S & $14-30$ & 6 & L & L & 2 & $2-3$ & G & & M. helleri \\
B, R & $25-50$ & 6 & T & L & $12-50$ & $12-50$ & I, G & D, S Pyura vittata \\
W & $17-23$ & $8-9$ & T & E & 1 & 1 & A & C & Herdmania pallida \\
\hline
\end{tabular}

\section{Microcosmus anchylodeirus Traustedt, 1883} Figs 2 and 7

Solitary ascidians, 3-9 $\mathrm{cm}$ long and 3-7 $\mathrm{cm}$ wide, red or wine colored when alive and red-brownish in formalin. Without the tunic, the body wall of the largest animals is $7.0 \mathrm{~cm}$ long and $5.5 \mathrm{~cm}$ wide. The tunic is wrinkled, thickest around the siphons, and completely encrusted by sand, algae and sessile invertebrates. Siphons are always far from each other but position varies and both could be apical or the atrial siphon could be displaced posteriorly. Both siphons have four small triangular or rounded lobes and a velum lining the internal wall - the oral velum is recovered by papillae and acicular spines; the atrial velum has small tentacles. The body wall is brown and rather opaque, but strong muscle bands radiate from the siphons on both sides. Internally there are 4-25 endocarps on the right side and 5-16 on the left, on the body wall and on the gonads.

There are 12-25 oral tentacles of three sizes, branched three times. Small papillae are in the space between the line of tentacles and the peripharyngeal groove. The dorsal tubercle aperture is horseshoe shaped with enrolled ends. The dorsal

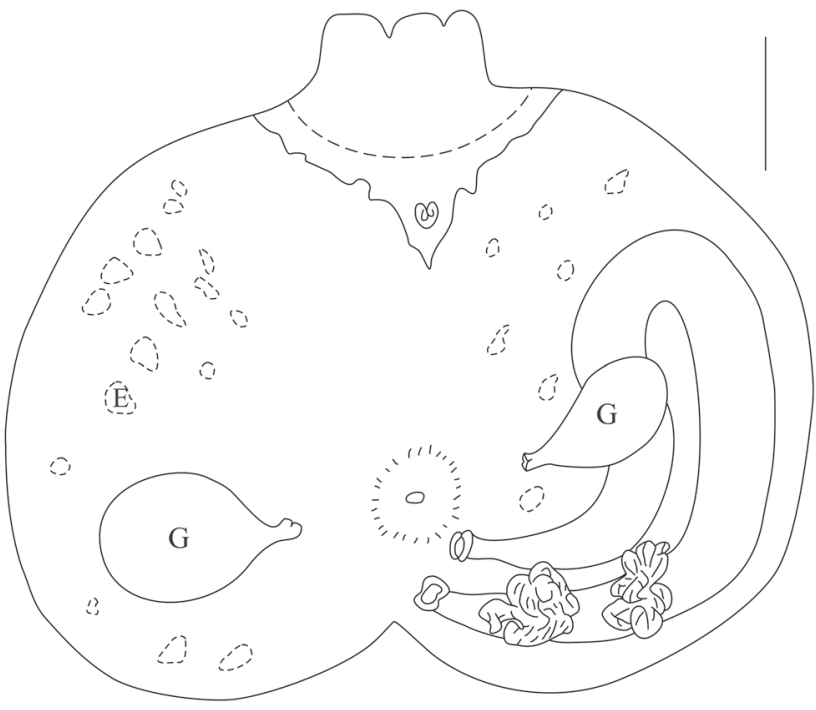

Figure 2. Microcosmus anchylodeirus, dissected individual without pharynx. (G) Gonad, (E) endocarp. Scale bar: $1.0 \mathrm{~cm}$.

lamina is simple, continuous and uniformly wide along its length; the margin is smooth. The pharynx has seven folds on each side with more than ten longitudinal stigmata per mesh. Parastigmatic vessels are present. The distribution of longitudinal vessels for a medium sized individual $(6 \mathrm{~cm})$ follows: right side - E 318620102110246236254193 DL; left side - DL $3244244265277276235152 \mathrm{E}$ and the total number of vessels is around 350 . Both sides of the endostyle have some papillae.

The stomach is long and covered by the digestive gland, which is yellow and divided into two portions. The lobes of the digestive gland are lamellar in shape. The primary intestinal loop is narrow and the secondary wide, ending in a bilobed anus.

The unlobed gonads are well adhered to the body wall. On the right side, the gonad is compact and round; on the left, it is more elongated, crossing the intestine as usual for this genus, and also spreading on the intestinal wall. Oviduct elongate with a slightly lobed aperture.

Examined material. Blackadder shipwreck, 6-7 m, 14.XII.2007 (2 ind., DZUP MIC31). Quebramar Norte (7-9 m depth), 06.VIII.1999 (2 ind., DZUP PYU32). 1 ind., Quebramar Norte (7-9 m depth), 06.VIII.1999 (1 ind., DZUP MIC18). Quebramar Norte (7 m depth), 08.VI.2004 (11 ind., DZUP MIC17). Quebramar Norte, 11.XII.2007 (10 ind., DZUP MIC29). Quebramar Sul, 07.VIII.1999 (4 ind., DZUP PYU31). Quebramar Sul (3 m depth), 10.VI.2004 (5 ind., DZUP MIC16). Bahia Marina, 03.VIII.1999 (1 ind., DZUP PYU34). Maraldi shipwreck (4-5 m depth), 10.XII.2007 (2 ind., DZUP MIC33). Barra bouy, 12.XII.2007 (1 ind., DZUP MIC35). Germania shipwreck (57 m depth), 10.XII.2007 (5 ind., DZUP MIC34). Porto da Barra 
(4 m depth), 06.VI.2004 (DZUP MIC19). Barra (11 m depth), 06.VI.2004 (5 ind., DZUP MIC15).

World Distribution. Brazil, Cuba, St. Thomas, Martinique. Remarks. Microcosmus anchylodeirus is very similar to $M$. multitentaculatus (Tokioka, 1953) described from Japan as recognized by Monniot (1983c) and Nishikawa (1991). Monniot (1983c) mentions that the only differences are the color of the animal and the larger number of pharyngeal longitudinal vessels in M. anchylodeirus, while NisHirawa (1991) only points to the difference in the level of oral tentacle ramification. Both characters can be plastic with size and Atlantic animals are larger than Pacific ones. Our specimens were more similar to the description of Caribbean animals and we identified them as $M$. anchylodeirus, but in our judgment, doubt remains about whether these two species should by synonymized. This is the first report of this species in Brazil.

\section{Microcosmus exasperatus Heller, 1878} Fig. 8

Given that it is a well known species and the characters agree well with descriptions (VAN NAME 1945, MonNiot 1983c, Котт 1985), only a diagnosis will be given here. Individuals have small sharp spines at the border of the oral siphon, 12-25 branched oral tentacles, the dorsal lamina is smooth, there are 8-10 folds in each side of the pharynx and 450-500 total number of longitudinal vessels, gonads are elongate with 3-5 lobes.

Examined material. Frades island, 07.VI.2004 (DZUP MIC13). Frades island (3-4 m depth), 15.XII.2007 (2 ind., DZUP MIC32). Itaparica pier, 04.VIII.1999 (1 ind., DZUP MIC24). Boa Viagem beach (7-8 m depth, shipwreck), 03.VIII.1999 (1 ind., DZUP PYU30). Quebramar Norte, 08.VI.2004 (3 ind., DZUP MIC08). Quebramar Norte (9 m depth), 11.XII.2007 (4 ind., DZUP MIC30). Quebramar Sul (2-3 m depth), 10.VI.2004 (5 ind., DZUP MIC10). Bahia Marina (3-6 m depth), 03.VIII.1999 (10 ind., DZUP PYU27). Porto da Barra (3-5 m depth), 16.XII.2007 (1 ind., DZUP MIC36).

Distribution along the coast of Brazil: Pernambuco (MILLAR 1977), Alagoas, Bahia, Espírito Santo (T.M.C. Lotufo, pers. comm. 2002), Rio de Janeiro (Rocha \& Costa 2005, Marins et al. 2010), São Paulo (Millar 1958, Rodrigues 1962, Rodrigues et al. 1998, Rocha et al. 2011), Paraná (Rocha \& NASSER 1998, Rocha \& Kremer 2005), Santa Catarina (Rodrigues 1962, Rocha et al. 2005b, Rосна et al. 2009). World Distribution: Brazil, Caribbean Sea, Mediterranean Sea, Atlantic and Indopacific.

\section{Microcosmus helleri Herdman, 1881}

Small individuals, $2.5-3.0 \mathrm{~cm}$ long and $2-3 \mathrm{~cm}$ wide, pale and usually encrusted by sand, algae and sessile invertebrates. Without the tunic the body wall is $2 \mathrm{~cm}$ long and $2 \mathrm{~cm}$ wide. Siphons are apical but far from each other. Both siphons have four small triangular lobes. A thick velum lines the internal wall of the oral siphon and is divided into four lobes. The atrial velum is thinner and delicate, also divided into lobes that are overlapping. Differently from other species of the genus Microcosmus, no spines were found on the siphons.

There are 14-18 oral tentacles of two sizes, branched three times. The peripharyngeal area is covered by minute papillae and the prepharyngeal grove has a double margin. The dorsal tubercle aperture is horseshoe shaped with enrolled ends. The dorsal lamina is simple, continuous and larger towards the esophageal opening; the margin is smooth. The pharynx has six folds on each side. Parastigmatic vessels are present. The distribution of longitudinal vessels for a large individual follows: right side - E 1156194206243203211 DL; left side - DL $2212164222225156101 \mathrm{E}$.

The stomach is covered by the digestive gland with lamellar lobes and papillae along the margin of each lamella. The intestine is strongly adhered to the body wall, without endocarps; the primary intestinal loop is narrow and the anus rim smooth.

The gonads are well adhered to the body wall, with short gonoducts. On the right side, it is formed by two lobes, while on the left, there are three lobes.

Examined material. Quebramar Norte (6-7 m depth), 08.VI.2004 (3 ind., DZUP MIC14). Bahia Marina (3-6 m depth), 03.VIII.1999 (3 ind., DZUP PYU29). Porto da Barra (4 m depth), 06.VI.2004 (DZUP MIC19).

Distribution along the coast of Brazil: Pernambuco (MillaR 1977), Bahia (Monniot 1969-70). World Distribution: Brazil, Caribbean Sea, Indo-West Pacific.

Remarks. The individuals agree well with the descriptions by Van Name (1945), Millar (1977) and Monniot (1969-70) for Atlantic material in all diagnostic characters: oral siphons without spines, but with a velum divided into four lobes anterior to the oral tentacles, six pharyngeal folds per side with 4-6 longitudinal vessels in the space between them, right gonad oval, either unique or divided into two portions. On the other hand, in individuals from Brazil, the lobes of the oral siphon velum are not thick or cartilaginous as in individuals from Australia, and there are no endocarps on the intestinal loop. Furthermore, exemplars from Australia have fewer longitudinal vessels on and between folds (Котт 1985). Specimens from Japan have the right gonad divided into two or three lobes and many more longitudinal vessels than specimens from Bahia (ТокіокA 1952, 1955).

\section{Pyura vittata (Stimpson, 1852)}

Fig. 9

This species is well known from the tropical Atlantic and complete descriptions can be found in VAN NAME (1945) and MonNiot (1983c). The diagnostic characters are: body globular or oval, with reddish pharynx in fresh animals; spines in the siphons; descendent portion of the intestine and rectum dilated; numerous lobes in each of the elongated gonads; right gonad curved or U-shaped; presence of large flattened endocarps on the intestine wall and gonads. 
Examined material. Itaparica pier, 04.VIII.1999 (1 ind., DZUP PYU56). Blackadder shipwreck (6-7 m depth), 14.XII. 2007 (1 ind., DZUP PYU 59). Boa Viagem beach (shipwreck), 03.VIII.1999 (1 ind., DZUP PYU33). Quebramar Norte (5-6 m depth), 08.VI.2004 (4 ind., DZUP PYU43). Quebramar Norte (9 m depth), 11.XII.2007 (9 ind., DZUP PYU 58). Quebramar Sul, 07.VIII.1999 (4 ind., DZUP PYU26). Quebramar Sul (3 m depth), 10.VI.2004 (4 ind., DZUP PYU45). Quebramar Sul (5$6 \mathrm{~m}$ depth), 14.XII.2007 (1 ind., DZUP PYU 61). Maraldi shipwreck (4-5 m depth), 10.XII.2007 (1 ind., DZUP PYU60). Germania shipwreck (5-7 m depth), 10.XII.2007 (12 ind., DZUP PYU62). Porto da Barra (4 m depth), 06.VI.2004 (1 ind., DZUP PYU49). Barra (10 m depth), 06.VI.2004 (1 ind., DZUP PYU48).

Distribution along the coast of Brazil: Pernambuco (Millar 1977), Bahia (Millar 1977), São Paulo (Rodrigues et al. 1998, Rocha \& Bonnet 2009). World Distribution: Brazil, Caribbean Sea, Indian and Pacific Oceans.

Remarks. The samples dissected here agree with the descriptions, but differ in some characters from the specimens described from Guadeloupe and Martinique by Monniot (1983c): animals from Bahia have fewer oral tentacles (around 25) and fewer longitudinal vessels in the pharynx (distribution of longitudinal vessels for a large individual follows: right side - E 7138156205215198145 DL; left side - E 41481510 $158206219145 \mathrm{DL}$ ). These differences may be explained by body size - Brazilian specimens are smaller than those from the Caribbean.

\section{Herdmania pallida (Heller, 1878)}

Fig. 10

This is a well known species and it will not be described here. Complete descriptions are found in (MonNiot 2002, NishiKaWA 2002). Diagnostic characters are: body more or less globular covered by a soft tunic; acicular spicules in the body wall and pharynx; spermiduct with single aperture. In fresh animals, the tunic is light pink, with internal wall of siphons blue and iridescent, and the gonads are orange.

Examined material. Canal Madre Deus (8 $\mathrm{m}$ depth), 07.VI.2004 (4 ind., DZUP HER12). Frades island (6 m depth), 07.VI.2004 (3 ind., DZUP HER08). Itaparica pier, 04.VIII.1999 (1 ind., DZUP HER17). Quebramar Norte, 08.VI.2004 (3 ind., DZUP HER05). Quebramar Norte, 11.XII.2007 (4 ind., DZUP HER20). Quebramar Sul (3 m depth), 10.VI.2004 (5 ind., DZUP HER07). Bahia Marina (3 m depth), 03.VIII.1999 (2 ind., DZUP PYU 28). Porto da Barra, 06.VI.2004 (1 ind., DZUP HER13). Jiribatuba (1 m depth), 09.VI.2004 (3 ind., DZUP HER09).

Distribution along the coast of Brazil (many previous records as H. momus): Alagoas (T.M.C. Lotufo, pers. comm. 2002), Bahia (Millar 1977), Rio de Janeiro (Rocha \& Costa 2005, Marins et al. 2010), São Paulo (Rodrigues 1962, Rodrigues et al. 1998, Rосна et al. 2011). World Distribution: Brazil, tropical West Atlantic, Indopacific.

\section{Styelidae Sluiter, 1895}

1 Coloration in life: B - Brown; O - Orange; S - Covered by sand; W - Whitish; Y - Yellowish

2 Number of oral tentacles

3 Shape of the ovary: S - Saculiform; E - Elongated

4 Number of gonads on the right side

5 Number of gonads on the left side

6 Attachment of gonads to the body wall: E - Embedded; A - Strongly attached; P - Attached by thin peduncle

7 Endocarps: A - Absent; B - On the body wall; I - On the intestinal wall

8 Number of endocarps inside intestinal loop

\begin{tabular}{ccccccccl}
\hline $\mathbf{1}$ & $\mathbf{2}$ & $\mathbf{3}$ & $\mathbf{4}$ & $\mathbf{5}$ & $\mathbf{6}$ & $\mathbf{7}$ & $\mathbf{8}$ & Species \\
\hline B & $50-60$ & S & $24-40$ & $15-33$ & A & B & 1 & Polycarpa arnoldi \\
Y & $36-56$ & S & $5-13$ & $4-7$ & A & B, I & $7-14$ & P. cf. reviviscens \\
W, B & $30-80$ & S & $30-100$ & $14-48$ & E, A & I & $1-3$ & P. spongiabilis \\
$?$ & $16-34$ & S & $20-45$ & $15-35$ & A & B, I & $2-7$ & P. tumida \\
S & 27 & S & 44 & 21 & P & A & 0 & Polycarpa sp. \\
B & 30 & E & 2 & 2 & A & B & $7-11$ & Styela canopus \\
B, O & $20-30$ & E & 3 & 2 & A & B, I & 5 & Cnemidocarpa irene \\
\hline
\end{tabular}

\section{Polycarpa arnoldi (Michaelsen, 1914)}

The only individual found was $2.9 \mathrm{~cm}$ long and $2.5 \mathrm{~cm}$ wide, oval shaped. The tunic is opaque, whitish and easily torn out, covered by sediment and encrusted algae and other ascidians. Both siphons are apical, close and have a smooth rim, slightly undulated. The body wall has spots of pigment and conspicuous longitudinal muscle bands, radiating from the siphons to the posterior margin.

There are 59 alternating large and smaller oral tentacles. The dorsal lamina has a plain rim and disappears after the esophagus aperture. The peripharyngeal groove has a double margin and forms a V-shaped region around the dorsal tubercle, whose aperture is like an inverted S.

The pharynx has four folds on each side with six stigmata per mesh. There are four sizes of transverse vessels and parastigmatic vessels are present. The distribution of longitudinal vessels is as follows: right side - E 5165165167122 DL; left side - E 4166145154174 DL.

The alimentary canal is short, occupying the posterior region of the left side. The stomach is large with 14 longitudinal folds. The primary intestinal loop is filled by a large endocarp. The anus has a plain rim.

Gonads are characteristic in this species. The ovary is surrounded by the testis follicles, forming flower-like structures. The individual dissected had 40 ovaries on the right side of the body wall and 33 on the left side, with up to eight testis follicles surrounding each ovary. The oviduct is much wider than the spermiduct. 
Examined material. Bahia Marina (3-6 m depth), 03.VIII.1999 (1 ind., DZUP STY85).

World distribution: Brazil, Caribbean Sea, Indian Ocean.

Remarks. This is the first report of this species from Brazil and it agrees well with previous descriptions (Millar 1962, VAN DER SLOOT 1969).

\section{Polycarpa cf. reviviscens Monniot \& Monniot, 2001}

Figs 3-5

Individuals are elongate, $2.6-3.5 \mathrm{~cm}$ long and $1.6-1.7 \mathrm{~cm}$ wide, with a stalk of variable length at the base. The tunic is thin but resistant and not very wrinkled and was encrusted by algae in our specimen. The body wall is almost uncolored and transparent through which it is possible to see the gonads and part of the alimentary canal. The corporal musculature is formed by very thin, almost inconspicuous, fibers. Without the tunic the body is $2.2-2.6 \mathrm{~cm}$ long including the oral siphon, and $1.0-1.2 \mathrm{~cm}$ wide.

The 6-9 mm long oral siphon is apical while the $4-5 \mathrm{~mm}$ long atrial siphon is located at the mid point of the dorsal margin. Both have four small round lobes. Internally the oral siphon is lined by a velum. The atrial siphon also has a short velum, and numerous (36 to 56) long and slender tentacles of three sizes. The prepharyngeal groove is simple and forms a deep $\mathrm{V}$ around the dorsal tubercle, which is small and may be a simple slit or horseshoe-shaped. The dorsal lamina has a smooth rim, is uniformly wide along its extension and ends after the esophagus aperture. The pharynx has four folds on each side and five to six stigmata per mesh. Parastigmatic vessels are conspicuous in parts of the pharynx. The distribution of longitudinal vessels in a medium-size individual is as follows: right side - E 58696 105104 DL; left side - E 61059510593 DL.

The alimentary canal is short, occupying the posterior region of the left side. The esophagus is short and the stomach small with 15-16 internal folds. The primary intestinal loop is close and followed by a wide secondary loop, both loosely attached to the body wall. The anus has 12-18 long lobes. In the body wall there are 58-71 foliaceous endocarps on the right side, 39-67 on the left and 7-14 within the primary intestinal loop.

The gonads are sacular, elongate and extensively attached to the body wall. They are aligned in the middle of the body, closer to the ventral margin. There are 5-13 on the right side of the body wall and only 4-7 on the left side, with the testis follicles hidden by the ovary when viewed from the atrial cavity. Both gonoducts end close to the atrial siphon and have an undulate aperture.

Examined material. Pedra Verde (23 m depth), 07.VIII.1999 (2 ind., DZUP POLC26). Quebramar Norte (6 m depth), 08.VI.2004 (2 ind., DZUP POLC03).

World distribution of $P$. reviviscens: Papua New Guinea, Solomon Islands, New Caledonia.

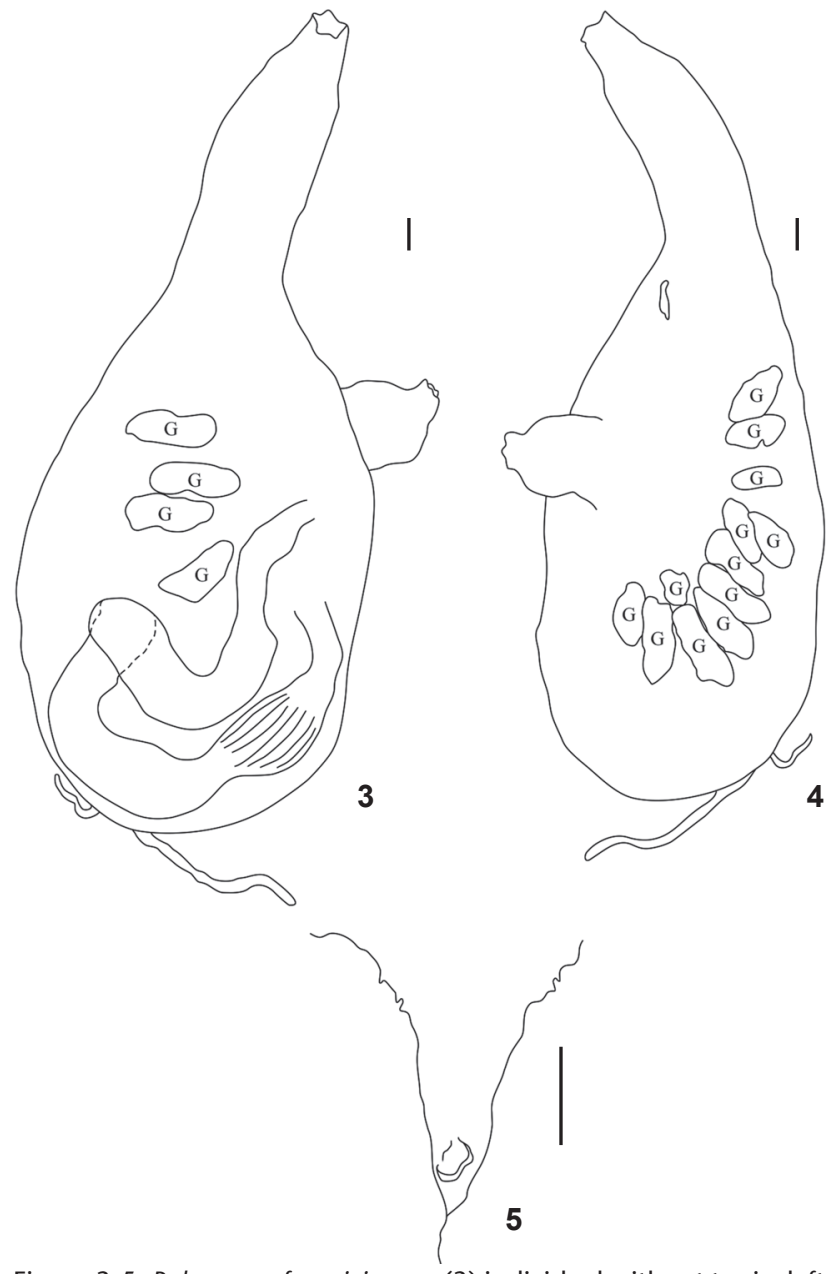

Figure 3-5. Polycarpa cf. reviviscens: (3) individual without tunic, left side; (4) individual without tunic, right side; (5) anterior region with dorsal tubercle. (G) Gonad. Scale bars: $1.0 \mathrm{~mm}$.

Remarks. The specimens dissected agree with the original description in MonNiot \& MonNiot (2001), the main difference is in the disposition of the gonads: $P$. reviviscens has gonads scattered in the body wall (Monniot 1987, Monniot \& Monniot 2001), while the specimens dissected here had gonads aligned more or less in the middle of the body. Due to this difference, and the distance between Brazilian and Pacific populations, some doubts arise about the correct identification of the species. Only a molecular study will reveal if the Brazilian specimens are the introduced $P$. reviviscens or a new species belonging to a group of species $P$. reviviscens sensu lato. The linear position of the gonads resembles $P$. captiosa (Sluiter, 1885) and $P$. foresti (Monniot, 1969-70), but $P$. captiosa has a meandering dorsal tubercle, more numerous gonads and the anus has a plain rim (Monniot \& Monniot 1996), differing from $P$. reviviscens. Polycarpa foresti, a species collected only in Bahia, 
also has few aligned gonads (eleven on the right side and seven on the left), while the specimen described by MonNiot (196970) has more longitudinal vessels on each side, the fourth fold does not reach the esophagus aperture, there are four lobes in the anus aperture and the endocarps are concentrated posteriorly to the gonads. None of those characteristics were seen in our specimens. Monniot \& Monniot (2001) noted the similarity between $P$. reviviscens and $P$. papillata (Sluiter, 1885), since both species are pedunculate, with numerous endocarps and a multilobed anus. However, $P$. papillata reaches $8.0 \mathrm{~cm}$ total length, the tunic around the siphons is red or has red stripes, has 1520 longitudinal vessels on the folds and 2-6 longitudinal vessels between them and there is no cloacal velum (Котт 1985, Monniot 1987, Monniot \& Monniot 2001). While Котт (1985) named all specimens studied as $P$. papillata, she emphasized the morphological differences between the larger and smaller individuals. Therefore Monniot \& Monniot (2001) proposed the separation into $P$. papillata, $P$. captiosa and $P$. reviviscens.

\section{Polycarpa spongiabilis Traustedt, 1883}

This species is well known from the tropical Atlantic and complete descriptions can be found in VAN NAME (1921) and MonNiot (1983b). Thus only diagnostic characters will be provided here: animals from 3 to $5 \mathrm{~cm}$ in diameter, tunic thick an cartilaginous, body wall opaque and usually brown, four folds on left side of the pharynx, but an extra $5^{\text {th }}$ dorsal pharyngeal fold can be observed on the right side; 10-20 stigmata per mesh; one large round, fleshy endocarp, and one or two smaller ones, are inside the primary intestinal loop, numerous sacular gonads in each side of the body are strongly attached to, or embedded in, the body wall.

Examined material. Frades island (6 $\mathrm{m}$ depth), 07.VI.2004 (2 ind., DZUP POLC01). Quebramar Norte (7-9 m depth), 06.VIII.1999 (1 ind., DZUP STY88). Quebramar Norte, 08.VI.2004 (1 ind., DZUP POLC24). Quebramar Norte, 11.XII.2007 (1 ind., DZUP POLC20). Bahia Marina (3-6 m depth), 03.VIII.1999 (2 ind., DZUP POLC25).

Distribution along the coast of Brazil: Ceará, Rio Grande do Norte, Pernambuco, Bahia (Millar 1977), São Paulo (Rodrigues et al. 1998), Santa Catarina (Van Name 1945, Rocha et al. 2009). World Distribution: Brazil, Caribbean Sea.

\section{Polycarpa tumida Heller, 1878}

\section{Fig. 6}

Individuals are $2.0 \mathrm{~cm}$ long and $0.5 \mathrm{~cm}$ wide, without the tunic. The tunic is leathery and wrinkled, light colored and slightly encrusted by sand, algae, and shell fragments. Siphons form short elevations with the oral apically and the atrial in the middle of the dorsal line. The body wall is brown, thick and opaque with delicate, almost inconspicuous, musculature. The oral siphon is lined by a velum and has approximately 30 simple oral tentacles around its base. The dorsal tubercle is large, very protruding, with a C-shaped aperture. The dorsal lamina is uniformly wide along its length, with a smooth margin. Four folds are on each side of the pharynx and six stigmata per mesh crossed by parastigmatic vessels. The distribution of longitudi-

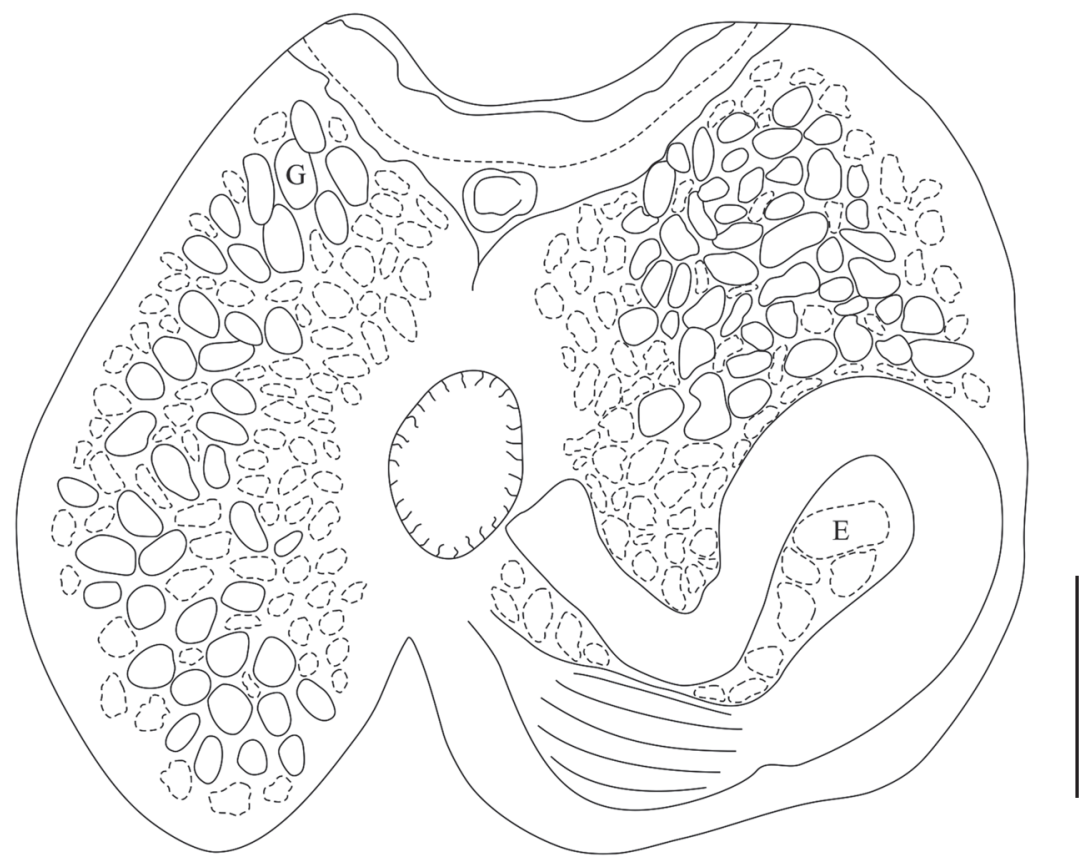

Figure 6. Polycarpa tumida, dissected individual without pharynx. (G) Gonad, (E) endocarp. Scale bar: $0.5 \mathrm{~cm}$. 

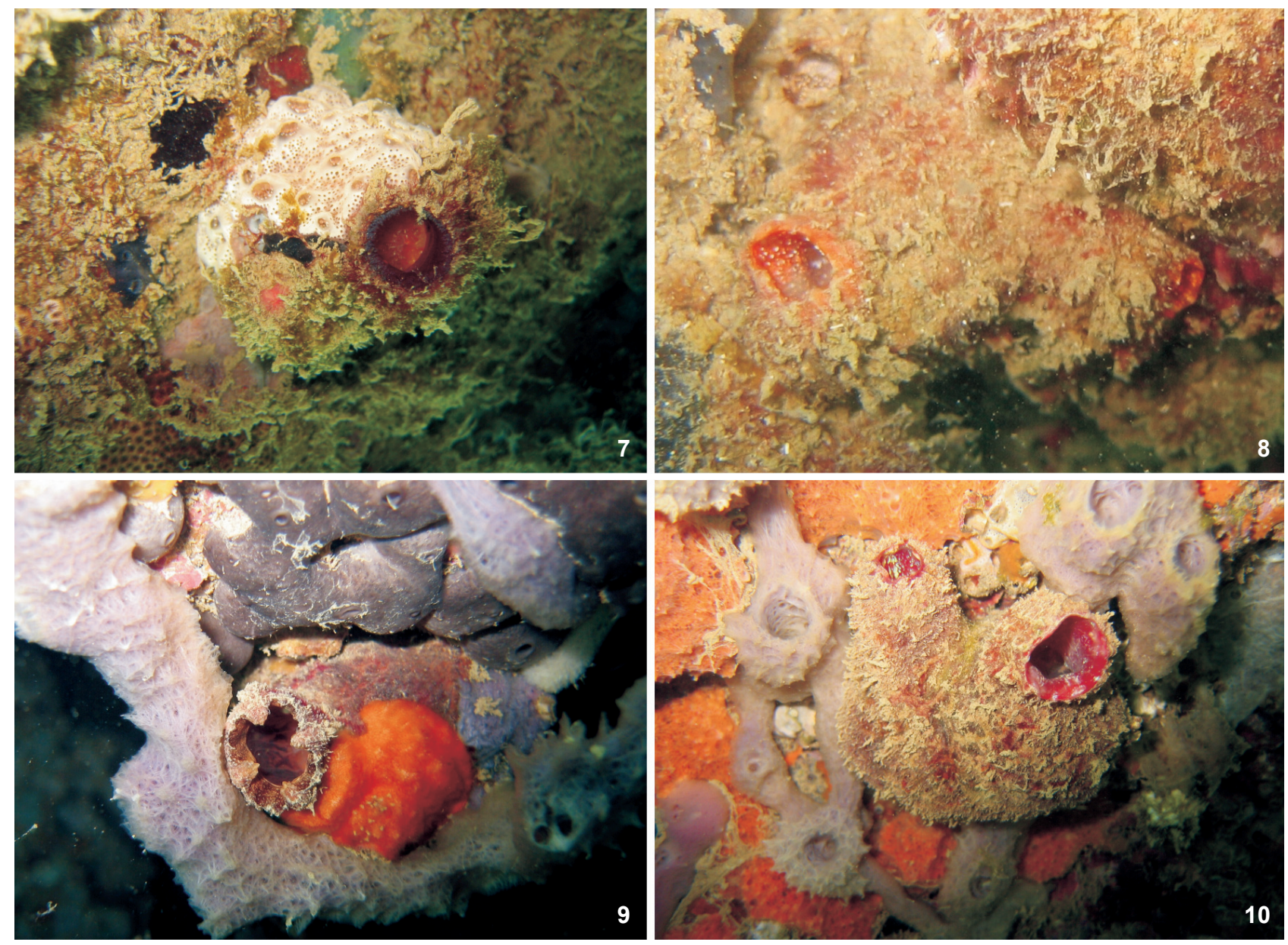

Figures 7-10. Animals in the field: (7) Microcosmus anchylodeirus; (8) Microcosmus exasperatus; (9) Pyura vittata; (10) Herdmania pallida.

nal vessels for one individual follows: right side - E 192132 $121141 \mathrm{DL}$; left side - E $192142122152 \mathrm{DL}$.

The alimentary canal occupies half or less of the left side, and is formed by a barrel-like stomach, with nine longitudinal folds; intestine completely attached to the body wall, anus with a typhlosole and smooth rim. The aperture of the atrial siphon is bordered by short and thin tentacles.

The gonads are sac-like, completely attached to the body wall and covered by an opaque membrane; there are 35-45 on each side of the body, each with 5-7 testis follicles. Numerous small flattened endocarps appear on both sides of the body wall and within the intestinal loop, where they are larger.

Examined material. Itaparica pier, 04.VIII.1999 (3 ind., DZUP POLC10).

World Distribution: Brazil, Caribbean Sea, West Pacific.

Remarks. Although registered as a colonial species by VAN DER SLOOT (1969) under the name Polyandrocarpa tumida, MONNIOT (1972a) could not find any connections among aggregated in- dividuals and placed them in the genus Polycarpa. Individuals from Curaçao have a greater number of ventral gonads (VAN DER SLOOT 1969) than those in this study. Those from French Polynesia differ from the Caribbean samples by having fewer longitudinal vessels and more (10-15) folds on the stomach wall (Monniot \& Monniot 1987). This is the first record of this species in Brazil.

\section{Polycarpa sp.}

Solitary ascidian, $6.5 \mathrm{~cm}$ in length and $3.0 \mathrm{~cm}$ wide with tunic, attached by a long stalk in the posterior region of the body. The tunic is firm, covered with sediment and epibionts, with only the yellow siphons visible. The body wall is yellowish in formaldehyde, opaque, with few conspicuous muscles.

The oral siphon is apical with four rounded lobes and the atrial is smooth and located in the midline of the body. The oral siphon is lined by a thick velum. There are 27 simple oral tentacles and a simple prepharyngeal groove forming a $\mathrm{V}$ 
around the peritubercular region. The dorsal tubercle is Ushaped. The pharynx has four folds on each side and 3-4 longitudinal stigmata per mesh. Parastigmatic vessels are present. The distribution of longitudinal vessels for one individual follows: right side - E 10158168206106 DL; left - E 169718 $9226109 \mathrm{DL}$. The digestive tract is missing. There are short atrial tentacles. Gonads are sac-like and weakly adhered to the body wall where they are restricted to the ventral margin of the body. There are 44 gonads on the right side and 21 on the left. Endocarps are absent.

Examined material. Barra, 06.VI.2004 (1 ind., DZUP POLC28).

Remarks. The missing gut precludes identification of the specimen, although it is already sexually mature. Except for the large size of the only individual found, the characteristics are similar to those in P. nivosa (Sluiter, 1898): tunic covered by encrustations, few oral tentacles (20-25), U-shaped dorsal tubercle, the number and distribution of longitudinal vessels, 35 stigmata per mesh, presence of parastigmatic vessels, few gonads loosely attached and absence of endocarps (VAN DER Sloot 1969, Millar 1977, Monniot 1983b). Eversion of the gut may have caused its loss, since the gut is loosely attached to the body wall (Millar 1977) and similar cases have been recorded for P. papillata (Sluiter, 1885) (Котт 1985). Polycarpa nivosa was previously registered in Brazil in Ceará and Pernambuco. If confirmed, this record will be an extension of its southern geographical limit.

\section{Styela canopus (Savigny, 1816)}

This species has a wide geographical distribution in tropical and subtropical regions but the native geographical origin is still not known. Given that it is a well known species and the characters agree well with descriptions (VAN NAME 1945 as Styela partita, Котт 1985), only the diagnostic characters will be mentioned: small individuals, tunic leathery but thin, white rays inside the siphons, four folds in each side of the pharynx, stomach with 20-30 longitudinal folds, only two elongated gonads in each side of the body.

Examined material. Quebramar Norte (7-9 m depth), 07.VIII.1999 (2 ind., DZUP STY89). Bahia Marina (3-6 m depth), 03.VIII.1999 (2 ind., DZUP STY87).

Distribution along the coast of Brazil: Rio Grande do Norte, Pernambuco, Bahia (T.M.C. Lotufo, pers. comm. 2002), Rio de Janeiro (Monniot 1969-70, Marins et al. 2010), São Paulo (Rodrigues et al. 1998, Rocha \& Bonnet 2009), Paraná (Rocha \& Kremer 2005), Santa Catarina (Rocha et al. 2005b, Rocha et al. 2009). World Distribution: Brazil, Caribbean Sea, Atlantic and Pacific Oceans.

\section{Cnemidocarpa irene (Hartmeyer, 1906)}

Individuals are $2.1-2.7 \mathrm{~cm}$ long with the tunic. The tunic is thin, translucent and soft, encrusted by some algae and barnacles. The body is sac-like, $2.0-2.5 \mathrm{~cm}$ long and $1.5-2.0 \mathrm{~cm}$ wide without tunic. The siphons are apical and darker then the body; the oral around $0.5 \mathrm{~cm}$ and atrial $0.8 \mathrm{~cm}$. The body wall is transparent with longitudinal musculature formed by thick fibers and a weak transverse musculature.

The oral siphon has a large velum and 20-23 simple oral tentacles alternated with several very small papillae-like tentacles. The dorsal tubercle is U-shaped with almost touching ends, one end may be slightly enrolled inwards. Dorsal lamina is continuous with undulated margin. The pharynx has four folds on each side of the body, 7-8 longitudinal stigmata per mesh and parastigmatic vessels in parts of the pharynx. The distribution of longitudinal vessels for one individual follows: right side - E 78610511693 DL; left side - E 39410511 794.

Two endocarps are on each side of the body, and another five are inside the intestinal loop. The stomach is dilated with numerous internal folds (about 20). The anus has a multilobed margin. The atrial tentacles are small and sparse.

The gonads are elongated, two on the left, anterior to the intestine, and three on the right.

Examined material. Quebramar Norte (6 m depth), 11.XII.2007 (4 ind., DZUP CNE01).

Distribution along the coast of Brazil: Bahia (this study), São Paulo (Rocha et al. 2011). World distribution: Brazil, Guadeloupe, Australia, New Caledonia, Japan, Fiji, Hong Kong.

Remarks. The specimens agree very well with descriptions of Guadeloupe material (MonNioT 1983b) except for the fewer endocarps in Bahia specimens. Material. Monniot (1983b) named this species Cnemidocarpa areolata (Heler 1878), but later Monniot \& Monniot (1984) revised this identification after seeing Heller's type and placed the Caribbean specimens in $C$. valborg. NishiKaWA (1991) synonymized C. valborg and C. irene which has priority.

\section{DISCUSSION}

In this study in Todos os Santos Bay, we found 19 species of solitary ascidians, of which only five were previously known from the region: Ascidia cf. multitentaculata, Herdmania pallida, Microcosmus helleri, Pyura vittata and Styela canopus (VAN NAME 1945, Monniot 1969-70). Three species are new occurrences for Brazil: Microcosmus anchylodeirus, Polycarpa cf. reviviscens and P. tumida. Besides these, Ascidia cf. tapuni and Cnemidocarpa irene were only recently reported (Rocha et al. 2011, BONNET \& Rосна 2011) and were considered introductions in Brazil. Previous surveys included dredged material that was collected offshore, outside the TSB, hence the absence of records of most species cannot be interpreted as new introductions and therefore each should be analyzed individually.

Microcosmus anchylodeirus is known from the Caribbean, with records from Cuba (Hernandez-Zanuy 1990), Martinique and St. Thomas (MonNiot 1983c). Although widespread in the Salvador region, this species was not found in recent surveys in Rio de Janeiro (Rocha \& Costa 2005, Marins et al. 2010). It is a large animal with distinguishing characteristics that could 
not be confounded with $M$. exasperatus, the commonest species in Brazil. The possible synonymy with M. multitentaculatus, which is a Pacific species, would make this record an introduction in Brazil. If $M$. anchylodeirus is indeed a new species from the west Atlantic, it must be considered cryptogenic, due to its localized distribution in Brazil and disjunct distribution with respect to Caribbean populations. Especially because it is not widespread in the Caribbean and the original geographical range is unknown.

Polycarpa reviviscens is a west Pacific species found in New Caledonia, Solomon Islands and Papua New Guinea (type locality) (Monniot \& Monniot 2001). It was confounded with $P$. papillata in the literature and so its geographical range could be larger. If the identification of the present samples is confirmed, this will be the first record of this species in the Atlantic.

Polycarpa tumida was first described from material of Jamaica, but it is not widespread in the Caribbean being recorded only in Bermuda, Belize, Cuba and Guadeloupe (Rocha et al. 2005a). There are also records outside the Caribbean in French Polynesia (Monniot \& Monniot 1987) and Palau (Monniot \& Monniot 2001) in the Pacific. This is the first record for Brazil and since we found only three individuals on a small pier it is likely to have been recently introduced, even though its native geographical distribution remains unknown.

Ascidia tapuni is known from Tahiti, New Caledonia, Fiji Islands and Indonesia (MonNiot \& MonNiot 2008). Only two individuals were collected in Brazil, one in Bahia and one in Rio de Janeiro, both in habitats usually colonized by introduced species (the first was near a port and the second on an aquaculture structure). If this identification is confirmed, this will also be the first record of this species in the Atlantic.

Cnemidocarpa irene is widely distributed throughout the Indo-Pacific (Kотт 1985, as C. areolata), and was found only in the Atlantic in Guadeloupe (MоNNIOT 1983b) and more recently in São Paulo, Brazil (Rocha et al. 2011).

The following species have worldwide distributions and were classified as cryptogenic because their original geographic distributions are unknown: Phallusia nigra, Herdmania pallida, Microcosmus exasperatus, M. helleri, Pyura vittata and Styela canopus. Phallusia nigra was first described from the Red Sea but most records come from the west Atlantic. Also, the analysis of 10 allozyme systems had high levels of heterozygosity among populations between Miami and south Brazil. Additionally, the Western Atlantic populations of P. nigra comprise a single species with high gene flow (Nobrega et al. 2004), suggesting that this could be the native geographical distribution of the species. Comparison with species from the Red Sea and Indian Ocean are still needed for a definition of the native range of this species. Even though recent revisions of the genus Herdmania showed that the only species in the Atlantic is $H$. pallida (Котт 2002, MonNiot 2002, NishiKawa 2002), this species is also found throughout the Indian and Pacific oceans. The fact that it is the only species found in the Atlantic suggests previous speciation followed by dispersal, but we do not know if the dispersion was human mediated nor how old it is. Microcosmus helleri has a disjunct distribution in the Atlantic with records in the Caribbean and northeastern Brazil (MilLaR 1977, MonNiot 1969-70). Given that this species is widely spread in Pacific and Indian waters, an introduction into the Atlantic is likely. Rodrigues (1966) reported $P$. vittata for the first time in Brazil in São Paulo, where it is rare. In Bahia, in contrast, it was found in several places where it was relatively abundant (Tab. II). Although most of the records are from the tropical West Atlantic, it also occurs in India, Palau, Indonesia, Northwest Pacific, and New Caledonia (Nishikawa 1991, Токіока 1950, MonNiot 1989).

Although Ascidia multitentaculata occurs only in the Atlantic, there are records on both sides, at Bahia (Millar 1977) and South Africa (Millar 1964), and the native range is unknown. Ascidia tenue distribution includes only Bermudas, Guadeloupe and Brazil. It is a rare species, usually hidden underneath rocks, crevices or inside empty shells. It is also uncolored and small which make it difficult to find. Moreover, it can be easily confused with $A$. curvata which is possibly an evolutionarily close species, suggesting a Caribbean origin for A. tenue. The rarity and isolated records of this species in Brazil suggests introduction, but the scattered records prevent us from a certain definition with respect to its introduced status.

Ascidia nordestina, A. papillata, A. scalariforme and Polycarpa spongiabilis are the only possibly native species in this collection. The first three because they were only recently described and no populations other than in Brazil are known. We recognize that many species were first described in their introduced range (CARLTON 2009), but think it unlikely in these cases. Polycarpa spongiabilis is very common in the Caribbean (VAn der Sloot 1969, Rocha et al. 2005a), Guyana (Millar 1978), and northern and northeastern Brazil (Millar 1977); it seems to be a typical tropical species that thrive in calm waters.

The large proportion of cryptogenic species in this region is in part due to the lack of historical reports of ascidians, which impedes our ability to detect new arrivals. The large numbers of cryptogenic species also indicates that the impact of invasion may be underestimated (CARLTON 1996). It is interesting that two introduced species common in south Brazil were not found in this study: Ascidia sydneiensis Stimpson, 1955 and Styela plicata (Lesueur, 1823). Styela plicata is a warm temperate species that probably does not survive well in the warm waters of Bahia, even though it was found once in Aratu Bay, attached to a barge hull (T.M.C. Lotufo, pers. comm. 2002). Ascidia sydneiensis, on the other hand, is abundant in tropical Caribbean regions (RосHA et al. 2005a) and was recently found on experimental panels deployed in a marina in the TSB (L.P. Kremer, pers. comm. 2011). As expected, Todos os Santos Bay is impacted by many introduced ascidians and probably by other taxonomic groups as well. Therefore, comprehensive surveys of fauna are needed to construct a baseline that will allow 
the detection of new arrivals. The effect of non-native species on natural communities and habitats such as the coral reefs occurring in the region is unknown and research programs to examine this potential problem and additional issues arising from introductions should be promoted.

\section{ACKNOWLEDGEMENTS}

We would like to thank Roberto G.S. Berlinck, coordinator of the project sponsored by FAPESP (2010/50190-2) for logistical support during sampling campaigns. RMR received a research grant from CNPq (304768/2010-3) and NYKB received a scholarship from CNPq and FSB from Fundação Araucária. Two anonimous reviewers helped to improve the quality of the manuscript, and J.J. Roper reviewed the English. This is contribution 1849 from the Departamento de Zoologia, UFPR.

\section{LITERATURE CITED}

Bonnet, N.Y.K. \& R.M. Rocha. 2011. The Ascidiidae (Ascidiacea, Tunicata) in coastal Brazil. Zoological Studies 50 (6): 809825.

Carlton, J.T. 1996. Biological invasion and cryptogenic species. Ecology 77 (6): 1653-1655.

Carlton, J.T. 2009. Deep invasion ecology and the assembly of communities in historical time, p. 13-56. In: G. Rilov \& J.A. CRooks (Eds). Biological Invasions in Marine Ecosystems. Heidelberg, Springer-Verlag.

Chapman, J.W. \& J.T. Carlton. 1991. A test of criteria for introduced species: The global invasion by the isopod Synidotea laevidorsalis (Miers, 1881). Journal of Crustacean Biology 11 (3): 386-400.

Chapman, J.W. \& J.T. Carlton. 1994. Predicted discoveries of the introduced isopod Synidotea laevidorsalis. Journal of Crustacean Biology 14: 700-714.

Hartmeyer, R. 1912. Die ascidien der Deutschen TiefseeExpedition. Deutschen Tiefsee-Expedition 16: 225-392.

Herdman, W.A. 1882. Report on the Tunicata collected during the voyage of H.M.S. Challenger during the years 1873-1876. I. Ascidiae simplices. Zoology, Challenger Expedition 6: 1-296.

Herdman, W.A. 1886. Report on the Tunicata collected during the voyage of the H.M.S. Challenger during the years 18731876. P. II - Ascidiae compositae. Report on the Scientific Results of the Voyage of H.M.S. Challenger during the years 1873-1876 14 (38): 1-429.

Hernandez-Zanuy, A. 1990. Lista de ascidias cubanas. Poeyana 388: 3-7.

Котт, P. 1985. The Australian Ascidiacea part 1, Phlebobranchia and Stolidobranchia. Memoires of the Queesland Museum 23: 1-400.

Kотт, P. 2002. The genus Herdmania Lahille, 1888 (Tunicata. Ascidiacea) in Australia waters. Zoological Journal of the Linnean Society 134: 359-374.
LAMBERT, G. 2003. Marine biodiversity of Guam: the Ascidiacea. Micronesica 35-36: 588-597.

Lotufo, T.M.C. \& A.M.B. Silva. 2006. Ascidiacea do litoral Cearense, p. 221-247. In: H.M. CASCON \& T.M.C. Lotufo (Eds). Biota Marinha da Costa Oeste do Ceará. Fortaleza, MMA Probio.

Marins F.O.; R.L.M. Novaes; R.M. Rocha \& A.O.R. Junqueira. 2010. Non indigenous ascidians in port and natural environments in a tropical Brazilian bay. Zoologia 27 (2): 213-221.

Michaelsen, W. 1907. Tunicaten. Ergebnisse der Hamburger Magalhaensichen Sammelreise 1892-1893 1: 1-84.

Michaelsen, W. 1923. Neue und altbekannte Ascidien aus dem Reichmuseum zu Stockholm. Mitteillungen aus dem Zoollogischen Staatinstitut und Zoologischen Museum 40: 1-60.

Millar, R.H. 1958. Some ascidians from Brazil. Annals and Magazine of Natural History 13 (1): 497-514.

Millar, R.H. 1962. Some ascidians from the Caribbean. Studies of the Fauna of Curaçao and Other Caribbean Islands 59 (13): 61-77.

Millar, R.H. 1964. South African ascidians collected by Th. Mortensen, with some additional material. Videnskabelige Meddelelser Fra Dansk Naturhistorisk Forening 127: 159180.

Millar, R.H. 1977. Ascidians (Tunicata: Ascidiacea) from the Northern and North-eastern Brazilian shelf. Journal of Natural History 11 (2): 169-223.

Millar, R.H. 1978. Ascidians from the Guyana shelf. Netherlands Journal of Sea Research 12 (1): 99-106.

Monniot, C. 1969-70. Ascidies Phlébobranches et Stolidobranches. In: Résultats Scientifiques des Campagnes de la Calypso. Annales de I'Institut Océanographique 47: 33-59.

Monniot, C. 1972a. Ascidies Stolidobranches des Bermudes. Bulletin du Muséum National d'Histoire Naturelle, ser. 3, section A, 43 (57): 617-643.

Monniot, C. 1972b. Ascidies Phlebobranches des Bermudes. Bulletin du Muséum National d'Histoire Naturelle, ser. 3, section A, 61 (82): 939-948.

Monniot, C. 1983a. Ascidies littorales de Guadeloupe. II. Phlébobranches. Bulletin du Muséum National d'Histoire Naturelle ser. 4, section A, 5 (1): 51-71.

Monniot, C. 1983b. Ascidies littorales de Guadeloupe. IV. Styelidae. Bulletin du Muséum National d'Histoire Naturelle, ser. 5, section A, 4 (2): 423-456.

Monniot, C. 1983c. Ascidies littorales de Guadeloupe. VI. Pyuridae et Molgulidae. Bulletin du Muséum National d'Histoire Naturelle, ser. 5, section A, 5 (4): 1021-1044.

Monniot, C. 1987. Ascidies de Nouvelle-Calédonie. II. Les genres Polycarpa et Polyandrocarpa. Bulletin du Muséum National d'Histoire Naturelle, ser. 4, section A, 9 (2): 275-310.

Monniot, C. 1989. Ascidies de Nouvelle-Calédonie. IV. Pyuridae et Molgulidae. Bulletin du Muséum National 'dHistoire Naturelle, ser. 4, section A, 11 (3): 475-507. 
Monniot, C. 2002. Stolidobranch ascidians from the tropical western Indian Ocean. Zoological Journal of the Linnean Society 135: 65-120.

Monniot, C. \& F. Monniot. 1972. Clé mondiale des genres d'ascidies. Archives de Zoologie Experimentale et Génerale 113: 311-367.

Monniot, C. \& F. Monniot. 1984. Ascidies littorales de Guadeloupe VII. Especes nouvelles et complémentaires à l'inventaire. Bulletin du Muséum National d'Histoire Naturelle 4e ser, sect A, 6 (3): 567-582.

Monniot, C. \& F. Monniot. 1987. Les ascidies de Polynésie française. Mémoires du Muséum National d'Histoire Naturelle 136: 1-155.

Monniot, F. \& C. Monniot. 1996. New collections of ascidians from the tropical Western Pacific and Southeastern Asia. Micronesica 29 (2): 133-279.

Monniot, F. \& C. Monniot. 2001. Ascidians from the tropical western Pacific. Zoosystema 23 (2): 201-383.

Monniot, F. \& C. Monniot. 2008. Compléments sur la diversité des ascidies (Ascidiacea, Tunicata) de l'ouest Pacifique tropical. Zoosystema 30 (4): 799-872.

Nishikawa, T. 1991. The ascidians of the Japan Sea. II. Publications of the Seto Marine Biological Laboratory 35 (1/3): 25-170.

NishiKAWA, T. 2002. Revision of the ascidiacea genus Herdmania (Urochordata: Ascidiacea) inhabiting Japonese waters. Species Diversity 7 (3): 217-250.

Nobrega, R.; A.M. Sole-Cava \& C.A.M. Russo. 2004. High genetic homogeneity of an intertidal marine invertebrate along 8000 $\mathrm{km}$ of the Atlantic coast of the Americas. Journal of Experimental Marine Biology and Ecology 303: 173-181.

Rocha, R.M. \& C.M. Nasser. 1998. Some ascidians (Tunicata, Ascidiacea) from Paraná state, southern Brazil. Revista Brasileira de Zoologia 15 (3): 633-642.

Rосна, R.M. \& L.V.G. Costa. 2005. Ascidians (Urochordata: Ascidiacea) from Arraial do Cabo, RJ, Brazil. Iheringia, Série Zoologia, 95 (1): 57-64.

RochA, R.M. \& L.P. KREMER. 2005. Introduced Ascidians in Paranaguá Bay, Paraná, southern Brazil. Revista Brasileira de Zoologia 22 (4):1170-1184.

Rocha, R.M. \& N.Y.K. Bonnet. 2009. Ascídias (Tunicata, Ascidiacea) introduzidas no Arquipélago de Alcatrazes, São Paulo. Iheringia, Série Zoologia, 99 (1): 27-35.

Rocha, R.M; S.B. Faria \& T.R. Moreno. 2005a. Ascidians from
Bocas del Toro, Panamá. I. Biodiversity. Caribbean Journal of Science 41 (3): 600-612.

Rocha, R. M.; T.R. Moreno \& R. Metri. 2005b. Ascídias da Reserva Biológica Marinha do Arvoredo, SC. Revista Brasileira de Zoologia 22 (2): 461-476.

Rocha, R.M.; L.P. Kremer; M.S. Baptista \& R. Metri. 2009. Bivalve cultures provide habitat for exotic tunicates in southern Brazil. Aquatic Invasions 4: 195-205.

RochA, R.M.; G.M. DiAs \& T.M.C. Lotufo. 2011.Checklist das ascídias (Tunicata, Ascidiacea) do Estado de São Paulo, Brasil. Biota Neopropica 11 (1a): http://www.biotaneotropica.org.br/ v11n1a/en/abstract?inventory+bn0391101a2011

Rodrigues, S.A. 1962. Algumas ascídias do litoral sul do Brasil. Boletim da Faculdade de Filosofia Ciências e Letras Universidade de São Paulo, Série Botânica, 24: 193-216.

Rodrigues, S.A. 1966. Notes on Brazilian ascidians.1. Papéis Avulsos do Departamento de Zoologia 19 (8): 95-115.

Rodrigues, S.A.; R.M. Rocha \& T.M. Cruz Lotufo. 1998. Guia Ilustrado para Identificação das Ascídias do Estado de São Paulo. São Paulo, FAPESP, 190p.

Tокіока, T. 1950. Ascidians from the Palao Islands. Publications of the Seto Marine Biological Laboratory 1 (3): 115-150.

Токіока, Т. 1952. Ascidians collected by messrs. Renzi Wada and Seizi Wada from the pearl-oyster bed in the Arufa sea in 1940. Publications of Seto Marine Biological Laboratory 2 (2): 91-142.

Токіока, T. 1955. Contribution to Japanese ascidian fauna. XI. Sporadic memoranda 2. Publications of Seto Marine Biological Laboratory 4 (2-3): 205-218.

Traustedt, M.P.A. 1882. Vestindiske Ascidiae simplices. Forste afdeling. Phallusiadae. Videnskabelige Meddelelser fra Dansk Naturhistoriske Forening 1881: 257-88.

Traustedt, M.P.A. 1883. Vestindiske Ascidiae simplices. Anden afdeling. Molgulidae og Cynthiadae. Videnskabelige Meddelelser fra Dansk Naturhistoriske Forening 1882: 108-36.

VAN DER SLOOT, C.J. 1969. Ascidians of the family Styelidae from the Caribbean. Studies on the fauna of Curacao and other Caribbean islands 30 (110): 1-57.

VAN NAME, W.G. 1921. Ascidians of the West Indian region and Southeastern United States. Bulletin of the American Museum of Natural History 44 (16): 283-494.

VAN NAME, W.G. 1945. The North and South American ascidians. Bulletin of the American Museum of Natural History 84: 1-476.

Submitted: 24.VIII.2011; Accepted: 22.XII.2011.

Editorial responsibility: Paulo da Cunha Lana 